\title{
Wood properties of exotic larch grown in eastern Canada and north-eastern United States
}

\author{
by Y. H. Chui ${ }^{1}$ and Glenda MacKinnon-Peters ${ }^{2}$
}

\begin{abstract}
The rapid growth performance of exotic larch such as Japanese larch (Larix leptolepis (Sieb. et Zucc) Gord.) and European larch (Larix decidua Mill.) has attracted the attention of the forestry sector in eastern Canada and north-eastern United States for lumber and pulp production. While growth performance of these species in North America has been well documented, little is known with regards to their wood properties. The objective of this study was to evaluate the primary lumber grade yields, mechanical properties, fiber length, specific gravity and cold-water soluble extractives of larch from plantations in Maine, Nova Scotia, New Brunswick and Prince Edward Island. Samples were obtained from a Japanese (age 31), three European (age 17, 34 and 63) and one Japanese $\times$ European hybrid (age 22-27) larch stands. It was found that the structural grade yields of these species were relatively low because of the influence of knots. The mechanical properties (modulus of rupture and modulus of elasticity) of the mature European larch appeared to be comparable with published data for some native softwood species. Fiber length, specific gravity and cold-water soluble extractive content of all samples were similar to those found for other softwood species which are used for pulp production. Fiber length of the juvenile wood of European larch was significantly shorter than that of mature wood. Extractive content was highest in newly formed heartwood. Contrary to common belief, extractive content in young trees may not be low.
\end{abstract}

Key words: Japanese larch (Larix leptolepis Gord.), European larch (Larix decidua Mill.), European $\times$ Japanese hybrid (Larix eurolepis), Wood properties, Lumber yields
Les performances de croissance rapide de mélèzes exotiques tel le mélèze japonais (Larix leptolepis (Sieb. et Zucc) Gord.) et le mélèze européen (Larix decidua Mill.) ont attiré l'attention du secteur forestier de l'est du Canada et du nord-est des États-Unis au niveau de la production de bois de sciage et de pâte. Alors que les performances de croissance de ces espèces en Amérique du Nord sont très bien documentées, nous savons très peu de chose sur les propriétés du bois de ces espèces. L'objectif de cette étude était d'évaluer les rendements lors du classement primaire du bois, les propriétés mécaniques, la longueur des fibres, la gravité spécifique et les particules solubles à l'eau froide des mélèzes issus de plantations du Maine, de la Nouvelle-Écosse, du Nouveau-Brunswick et de l'lle-du-Prince-Édouard. Des échantillons ont été obtenus d'un peuplement de mélèze japonais (âgé de 31 ans), de trois peuplements de mélèze européen (âgés de 17, 34 et 63 ans) et d'un peuplement de mélèze hybride japonais $\times$ européen (âgé entre 22 et 27 ans). L'étude a démontré que les rendements en fonction des classes structurales de ces espèces étaient relativement faibles par suite de la présence de noeuds. Les propriétés mécaniques (coefficient de rupture et coefficient d'élasticité) des mélèzes européens mûrs semblaient être comparables aux données publiées pour quelques espèces natives de résineux. La longueur des fibres, la gravité spécifique, et les particules solubles à l'eau froide en fonction du contenu des échantillons étaient semblables aux résultats répertoriés pour d'autres espèces de résineux utilisés dans la production de pâte. La longueur des fibres du bois juvénile du mélèze européen était significativement plus courte que celle du bois produit à maturité. Le plus grand nombre de particules solubles se retrouvaient dans le bois de coeur récemment formé. Contrairement à la croyance populaire, les particules solubles des jeunes arbres peuvent ne pas étre en faible quantité.

Mots clés: mélèze japonais (Larix leptolepis Gord.), mélèze européen (Larix decidua Mill.), hybride européen $\times$ japonais (Larix eurolepis), propriétés du bois, rendements du sciage

\section{Introduction}

In Europe and Asia, the larch genus (Larix Mill.) include some important species for lumber and pulp and paper production. In eastern Canada, the only native larch species is tamarack (Larix laricina (Du Roi) K. Koch.). Tamarack generally grows on relatively poor sites and therefore has a slow growth rate (LooDinkins et al. 1992). The wood of this species is dense, strong and relatively resistant to decay mainly due to its high extractive content in the heartwood (Mullins and McKnight 1981). These wood characteristics are good attributes for utilization as lumber. When the wood is converted into pulp, the high extractive content can cause problems with some pulping processes (Hatton 1986).

\footnotetext{
${ }^{1}$ Associate Professor Faculty of Forestry and Environmental Management, University of New Brunswick, Fredericton, New Brunswick, Canada E3B 6C2. ${ }^{2}$ Research Engineer, Wood Science and Technology Centre, Faculty of Forestry and Environmental Management, University of New Brunswick, Fredericton, New Brunswick, Canada E3B 6C2.
}

Interest in fast-growing species has led to the initiation of a number of trials of exotic larch species in eastern Canada and north-eastern United States. The major exotic larch species introduced into eastern Canada are Japanese larch (Larix leptolepis Gord.), European larch (Larix decidua Mill.) and European x Japanese hybrid (Larix eurolepis). These faster growing species can produce large volumes of fiber in a relatively short period of time compared with tamarack, but this is achieved at the expense of lower wood specific gravity. Lower specific gravity is usually associated with lower mechanical properties and pulp yield per volume of fiber. On the other hand, there is evidence that the extractive content in fast-grown young trees of these exotic larches is lower compared with tamarack because of the lower percentage of heartwood (Isebrands and Hunt 1975; Isebrands et al. 1982; Fowler et al. 1988).

While the growth performance of exotic larch species has been well documented (MacGillivaray 1969; Ker et al. 1983; Park and Fowler 1983; Fowler 1986; Fowler et al. 1988; LooDinkins et al. 1992), published information on wood quality of exotic larch species is limited. In eastern Canada, Fowler and 


\begin{tabular}{|c|c|c|c|c|c|c|}
\hline$\underline{\text { Sample }}$ & Location & Species & $\begin{array}{l}\text { Mean } \\
\text { DBH } \\
(\mathrm{mm})\end{array}$ & $\begin{array}{c}\text { No. } \\
\text { of } \\
\text { trees }\end{array}$ & $\begin{array}{l}\text { Age }^{1} \\
\text { (yrs) }\end{array}$ & $\begin{array}{l}\text { Initial spacing/ } \\
\text { thinning }\end{array}$ \\
\hline 1 & Maine, USA & $\begin{array}{c}\text { European } \times \\
\text { Japanese hybrid }\end{array}$ & 263 & 13 & $22 / 27$ & $\begin{array}{l}2.3 \mathrm{~m} \times 2.3 \mathrm{~m} / \\
\text { @age } 18,22 \mathrm{yrs}\end{array}$ \\
\hline 2 & Maine, USA & European larch & 394 & 21 & 63 & $\begin{array}{l}1.8 \mathrm{~m} \times 1.8 \mathrm{~m} / \\
\text { @ age } 41 \mathrm{yrs}\end{array}$ \\
\hline 3 & New Brunswick & Japanese larch & 261 & 25 & 31 & $\begin{array}{l}3.0 \mathrm{~m} \times 3.0 \mathrm{~m} / \\
\text { @ age } 24 \mathrm{yrs}\end{array}$ \\
\hline 4 & Nova Scotia & European larch & 227 & 15 & 17 & $\begin{array}{c}3.0 \mathrm{~m} \times 3.0 \mathrm{~m} / \\
\text { no thinning }\end{array}$ \\
\hline 5 & PEI & European larch & 213 & 26 & 34 & $\begin{array}{c}2.0 \mathrm{~m} \times 2.0 \mathrm{~m} / \\
\text { @ age } 25,31 \mathrm{yrs}\end{array}$ \\
\hline
\end{tabular}

${ }^{1}$ Year from planting

his co-workers (1988) have conducted limited wood property tests on a sample of 25-year-old Japanese larch. They also estimated the grade yields of their lumber samples. Keith and Chauret (1988) measured specific gravity, fiber dimensions, extractive contents and lignin content of wood from 23- and 28-year-old European larch. In the United States, Olson et al. (1947) conducted a study to determine the strength properties and specific gravity of plantation-grown coniferous woods. A 30 year old European larch plantation was sampled for testing by them. More recently, Isebrands and Hunt (1975) studied specific gravity and extractive content of 10-year old Japanese larch, and Einspahr et al. (1983) measured fiber lengths, specific gravity and extractive content of young European larch (18 years), Japanese larch (22 years) and European x Japanese larch hybrid ( 23 years) as part of a study on pulping characteristics. Where appropriate, wood property results from this study will be compared with the studies listed above.

To summarize, exotic larch species can achieve rapid growth rates in eastern Canada, but only limited data on wood properties is available. This study was conducted to help bridge this gap in information by testing materials sampled from plantations of Japanese, European and European x Japanese hybrid larch grown in eastern Canada and north-eastern United States. The objectives were :

1. To study yields for structural grade lumber.

2. To evaluate bending properties of lumber and clear wood.
3. To evaluate fiber length, specific gravity and cold-water extractive content, and their variations within a tree.

4. To provide an initial indication of how wood properties of exotic larch compared with some commercially important softwood species.

The first two objectives relate to the utilization of the material as structural lumber whereas the third focuses on pulping quality of the material.

\section{Materials and method}

Three European, one Japanese and one European $\times$ Japanese hybrid larch plantations were selected to provide the test material. These covered a number of geographical locations and a range of age classes. Details about planting spacing, thinning and number of trees sampled are given (Table 1).

After the trees were felled, they were cut into $3.05 \mathrm{~m}$ (10 ft)

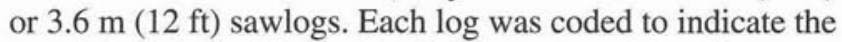
sample location and its position in the tree stem. These logs were transported to the Wood Science and Technology Centre, University of New Brunswick and converted into rough sawn two-by-four lumber pieces at a local sawmill. The lumber was kiln dried to a nominal $12 \%$ moisture content, and planed to the final dimensions of $38 \mathrm{~mm} \times 89 \mathrm{~mm}$. The planed lumber pieces were tested for modulus of elasticity (MOE) and modulus of rupture (MOR) in bending according to standard ISO 8375 (ISO 1985). The moisture content, gross specific grav-

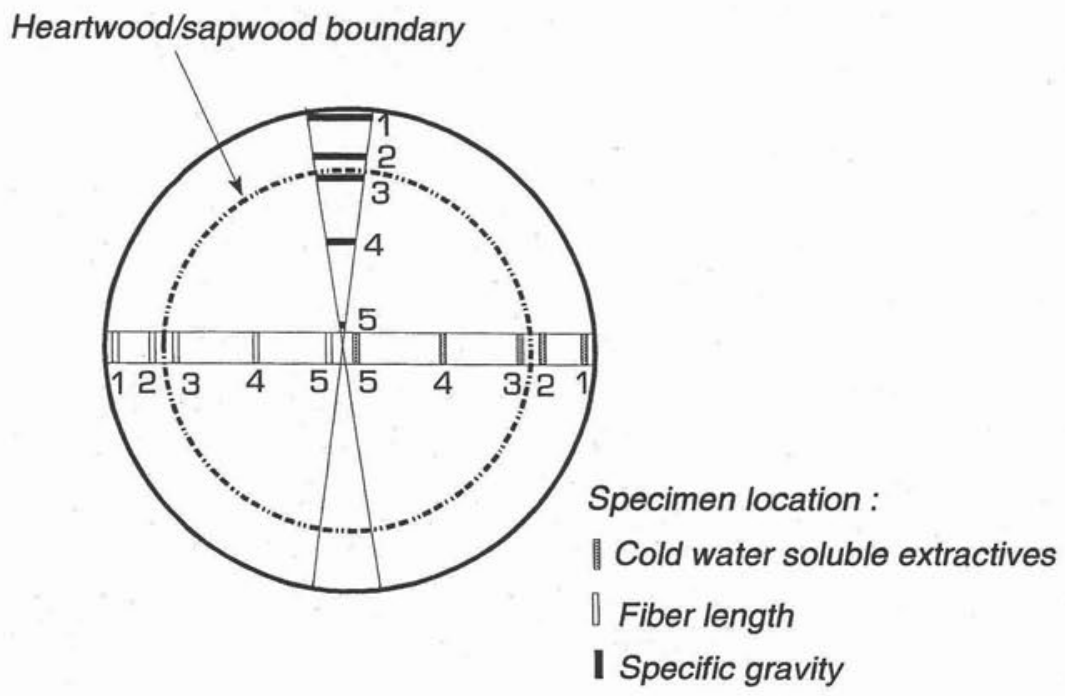

Figure 1. Sampling locations from a disc for fiber length, specific gravity and cold-water soluble extractive content measurements. 


\begin{tabular}{|c|c|c|c|c|c|c|c|c|}
\hline \multirow[t]{2}{*}{ Sample } & \multirow[t]{2}{*}{ Species/location } & \multirow[t]{2}{*}{ No. } & \multicolumn{6}{|c|}{ Visual grade $(\%)$} \\
\hline & & & SS & No.1 & No.2 & No.3 & $\mathbf{E}$ & Reject \\
\hline 1 & $\mathrm{~J} \times \mathrm{E}$ Hybrid, Maine & 74 & 7 & 36 & 43 & 14 & 0 & 0 \\
\hline 2 & European larch, Maine & 277 & 23 & 42 & 23 & 12 & 1 & 0 \\
\hline 3 & Japanese larch, New Brunswick & 126 & 13 & 55 & 26 & 6 & 0 & 0 \\
\hline 4 & European larch, Nova Scotia & 47 & 0 & 28 & 72 & 0 & 0 & 0 \\
\hline 5 & European larch, PEI & 76 & 9 & 59 & 32 & 0 & 0 & 0 \\
\hline
\end{tabular}

Table 3. Properties of lumber material

\begin{tabular}{|c|c|c|c|c|c|c|c|c|c|}
\hline \multirow[b]{2}{*}{ Sample } & \multirow[b]{2}{*}{ Species/location } & \multirow[b]{2}{*}{ No. } & \multicolumn{2}{|c|}{ Lumber bending } & \multicolumn{2}{|c|}{ Small clear bending } & \multirow[b]{2}{*}{$\begin{array}{c}\text { Specific } \\
\text { gravity }\end{array}$} & \multirow[b]{2}{*}{$\begin{array}{l}\text { MC } \\
(\%)\end{array}$} & \multirow[b]{2}{*}{$\begin{array}{l}\text { Growth rate } \\
(\mathrm{mm} / \mathrm{ring})\end{array}$} \\
\hline & & & $\begin{array}{l}\text { MOE } \\
\text { (MPa) }\end{array}$ & $\begin{array}{l}\text { MOR } \\
\text { (MPa) }\end{array}$ & $\begin{array}{l}\text { MOE } \\
\text { (MPa) }\end{array}$ & $\begin{array}{l}\text { MOR } \\
(\mathrm{MPa})\end{array}$ & & & \\
\hline 1 & $\mathrm{~J} \times \mathrm{E}$ Hybrid, Maine & 74 & $\begin{array}{l}7191 \\
(0.29)\end{array}$ & $\begin{array}{l}30.98 \\
(0.29)\end{array}$ & $\begin{array}{l}6178 \\
(0.25)\end{array}$ & $\begin{array}{l}55.12 \\
(0.18)\end{array}$ & $\begin{array}{l}0.404 \\
(0.10)\end{array}$ & $\begin{array}{l}13.00 \\
(0.07)\end{array}$ & $\begin{array}{c}7.31 \\
(0.28)\end{array}$ \\
\hline 2 & European larch, Maine & 277 & $\begin{array}{l}10937 \\
(0.28)\end{array}$ & $\begin{array}{l}43.76 \\
(0.36)\end{array}$ & $\begin{array}{l}9045 \\
(0.19)\end{array}$ & $\begin{array}{l}69.62 \\
(0.14)\end{array}$ & $\begin{array}{c}0.465 \\
(0.097)\end{array}$ & $\begin{array}{l}13.92 \\
(0.05)\end{array}$ & $\begin{array}{c}3.58 \\
(0.38)\end{array}$ \\
\hline 3 & Japanese larch, New Brunswick & 126 & $\begin{array}{l}8440 \\
(0.29)\end{array}$ & $\begin{array}{l}39.51 \\
(0.30)\end{array}$ & $\begin{array}{l}7061 \\
(0.24)\end{array}$ & $\begin{array}{l}63.29 \\
(0.21)\end{array}$ & $\begin{array}{l}0.442 \\
(0.09)\end{array}$ & $\begin{array}{l}12.80 \\
(0.05)\end{array}$ & $\begin{array}{c}5.77 \\
(0.28)\end{array}$ \\
\hline 4 & European larch, Nova Scotia & 47 & $\begin{array}{l}5934 \\
(0.21)\end{array}$ & $\begin{array}{l}27.26 \\
(0.29)\end{array}$ & $\begin{array}{l}5187 \\
(0.17)\end{array}$ & $\begin{array}{l}50.74 \\
(0.17)\end{array}$ & $\begin{array}{c}0.401 \\
(0.069)\end{array}$ & $\begin{array}{l}12.43 \\
(0.04)\end{array}$ & $\begin{array}{c}9.13 \\
(0.16)\end{array}$ \\
\hline 5 & European larch, PEI & 76 & $\begin{array}{l}8978 \\
(0.23)\end{array}$ & $\begin{array}{l}40.53 \\
(0.33)\end{array}$ & $\begin{array}{l}7431 \\
(0.24)\end{array}$ & $\begin{array}{l}64.28 \\
(0.15)\end{array}$ & $\begin{array}{c}0.456 \\
(0.079)\end{array}$ & $\begin{array}{l}13.30 \\
(0.07)\end{array}$ & $\begin{array}{c}4.64 \\
(0.33)\end{array}$ \\
\hline
\end{tabular}

Note : Values shown for properties are means with coefficient of variation given in parentheses

Table 4. Comparison of small clear wood bending properties with corresponding data in the literature

\begin{tabular}{|c|c|c|c|c|c|}
\hline Sample & Species/location & $\begin{array}{l}\text { MOE } \\
\text { (MPa) }\end{array}$ & $\begin{array}{l}\text { MOR } \\
(\mathrm{MPa})\end{array}$ & $\begin{array}{l}\text { Specific } \\
\text { gravity }\end{array}$ & Reference \\
\hline 1 & $\mathrm{~J} \times$ E Hybrid, Maine & 6178 & 51.12 & 0.404 & This study \\
\hline 2 & European larch, Maine & 9045 & 69.62 & 0.465 & This study \\
\hline 3 & Japanese larch, New Brunswick & 7061 & 63.29 & 0.442 & This study \\
\hline 4 & European larch, Nova Scotia & 5187 & 50.74 & 0.401 & This study \\
\hline 5 & European larch, PEI & 7431 & 64.28 & 0.456 & This study \\
\hline 6 & Norway spruce, New Brunswick & 7467 & 55.09 & 0.355 & Chui, 1993 \\
\hline 7 & Norway spruce, Nova Scotia & 7082 & 46.61 & 0.331 & Chui, 1993 \\
\hline 8 & Balsam fir, Canada & 9653 & 58.60 & 0.356 & FPL, 1987 \\
\hline 9 & Black spruce, Canada & 10480 & 78.60 & 0.434 & FPL, 1987 \\
\hline 10 & Red spruce, Canada & 11032 & 71.00 & 0.401 & FPL, 1987 \\
\hline 11 & White spruce, Canada & 9998 & 62.74 & 0.367 & FPL, 1987 \\
\hline 12 & Norway spruce, USA & 9929 & 58.60 & 0.356 & Olson et al, 1947 \\
\hline 13 & European larch, USA & 6964 & 58.60 & 0.356 & Olson et al, 1947 \\
\hline 14 & White spruce, USA & 9584 & 64.81 & 0.420 & Olson et al, 1947 \\
\hline
\end{tabular}

ity and growth rate of each bending specimen were determined from a small prism cross-cut from the specimen. In addition, a small clear (defect-free) specimen of dimensions $38 \mathrm{~mm} \times$ $38 \mathrm{~mm} \times 610 \mathrm{~mm}$ was machined from the undamaged part of each failed lumber piece. The small clear specimen was then tested for MOE and MOR according ASTM D143 (ASTM 1992). The rationale for including the small clear bending test was to provide a common basis for comparison with corresponding properties of other species. In total, 600 pieces of lumber and the same number of small clear specimens were tested.

From the first four plantations, cross sectional discs were obtained from three trees for measurement of fiber length, specific gravity and cold-water extractive content. These trees encompassed the DBH range for the plantation from which they were selected. For each of the three selected trees, a $50 \mathrm{~mm}$ thick disc was cut at the stump, $3.0 \mathrm{~m}$ and $6.0 \mathrm{~m}$ heights for samples one, two and four. For sample three, four discs at stump, $3.6 \mathrm{~m}, 7.2$ $\mathrm{m}$ and $11.0 \mathrm{~m}$ heights were obtained. The sampling locations for these tests on a disc (Fig. 1) included five measurements from the pith to bark for each property. Three measurements were in heartwood and two in sapwood. The objective was to observe any difference between sapwood and heartwood rather than radial age, particularly with respect to extractive content. The specific gravity was measured based on oven-dry weight and green volume. The method used for determining cold water-soluble extractive content largely followed TAPPI standard T207 OM-88 (TAPPI 1988) with minor modifications. The modifications to T207 OM-88 were introduced to accommodate difficulties in filtering. Fiber length was determined using a common method in which the wood is macerated in an acidic solution and then strained. A computer-based system was used to measure fiber lengths. Lengths of forty randomly selected complete fibers were measured for each sample, and the mean calculated to represent fiber length at each location. 


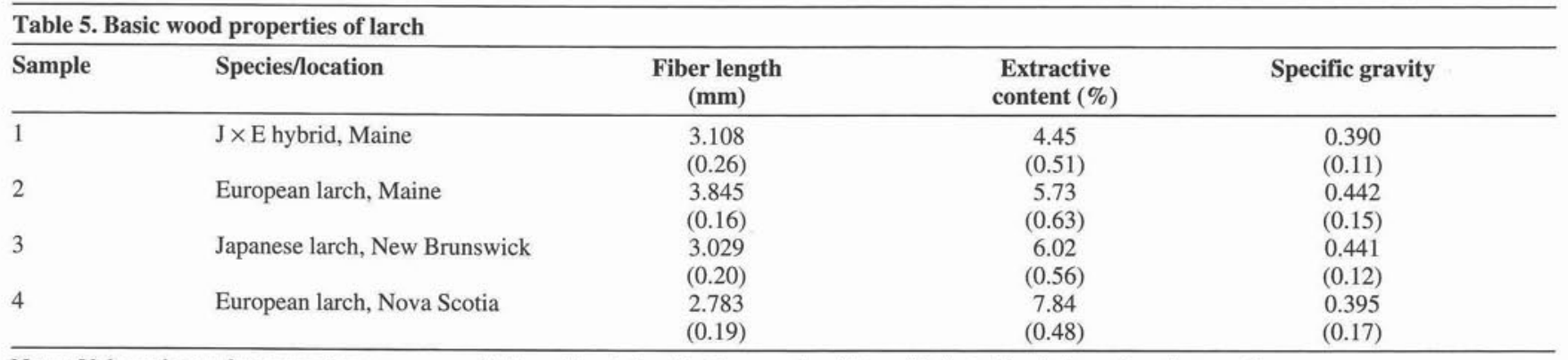

Note : Values shown for properties are means of all readings taken for the sample with coefficient of variation given in parentheses

Table 6. Comparison of basic wood properties with corresponding data in the literature

\begin{tabular}{|c|c|c|c|c|c|}
\hline Species/Location & $\begin{array}{l}\text { Age } \\
(\mathbf{y r})\end{array}$ & $\begin{array}{c}\text { Fiber length } \\
(\mathrm{mm})\end{array}$ & $\begin{array}{c}\text { Extractive } \\
\text { content }^{2}(\%)\end{array}$ & $\begin{array}{c}\text { Specific } \\
\text { gravity }\end{array}$ & Reference \\
\hline $\mathrm{J} \times \mathrm{E}$ hybrid, Maine & $22 / 27$ & 3.108 & $4.45(\mathrm{C})$ & 0.390 & This study \\
\hline European larch, Main & 63 & 3.845 & $5.73(\mathrm{C})$ & 0.442 & This study \\
\hline Japanese larch, New Brunswick & 31 & 3.029 & $6.02(\mathrm{C})$ & 0.441 & This study \\
\hline European larch, Nova Scotia & 17 & 2.783 & $7.84(\mathrm{C})$ & 0.395 & This study \\
\hline Japanese larch, USA & 22 & 3.16 & $7.4(\mathrm{H})$ & 0.384 & Einspahr et al, 1983 \\
\hline European larch, USA & 18 & 3.02 & $3.90(\mathrm{H})$ & 0.395 & Einspahr et al, 1983 \\
\hline $\mathrm{J} \times \mathrm{E}$ hybrid, USA & 23 & 2.75 & $4.2(\mathrm{H})$ & 0.413 & Einspahr et al, 1983 \\
\hline Jack pine, USA & 55 & 3.20 & $2.3(\mathrm{H})$ & 0.436 & Einspahr, et al 1983 \\
\hline Tamarack $^{1}$ & - & 3.6 & - & - & Hatton, 1986 \\
\hline Western larch ${ }^{1}$ & - & 5.0 & - & - & Hatton, 1986 \\
\hline European larch ${ }^{1}$ & - & 3.6 & - & - & Hatton, 1986 \\
\hline European larch, Ontario and Quebec & $23 / 28$ & 2.3 & $7.99(\mathrm{H})$ & 0.40 & Keith and Chauret, 1988 \\
\hline White pine ${ }^{1}$ & - & - & $2.1(\mathrm{H})$ & - & Hillis, 1962 \\
\hline Douglas fir ${ }^{1}$ & - & - & $6.5(\mathrm{H})$ & - & Hillis, 1962 \\
\hline Red pine, New Brunswick & 55 & 3.09 & - & 0.380 & Kaya, 1990 \\
\hline Japanese larch, USA & 10 & - & $2.0-6.0(\mathrm{H})$ & $0.3-0.45$ & Isebrands and Hunt, 1975 \\
\hline
\end{tabular}

${ }^{1}$ Location and age not known for these samples.

${ }^{2} \mathrm{C}=$ Cold-water soluble extractive content, $\mathrm{H}=$ Hot-water soluble extractive content

Table 7. Variation of lumber properties with $\log$ position in stem ${ }^{1}$

\begin{tabular}{|c|c|c|c|c|c|c|c|c|c|c|}
\hline \multirow[b]{2}{*}{ Sample } & \multirow[b]{2}{*}{ Species/Location } & & \multirow[b]{2}{*}{$\log ^{2}$} & \multirow[b]{2}{*}{ No. } & \multicolumn{2}{|c|}{ Lumber bending } & \multicolumn{2}{|c|}{ Small clear bending } & \multirow[b]{2}{*}{$\begin{array}{c}\text { Specific } \\
\text { gravity }\end{array}$} & \multirow[b]{2}{*}{$\begin{array}{l}\text { MC } \\
(\%)\end{array}$} \\
\hline & & & & & $\begin{array}{l}\text { MOE } \\
(\mathrm{MPa}) \\
\end{array}$ & $\begin{array}{l}\text { MOR } \\
(\mathrm{MPa}) \\
\end{array}$ & $\begin{array}{l}\text { MOE } \\
(\mathrm{MPa}) \\
\end{array}$ & $\begin{array}{l}\text { MOR } \\
(\mathrm{MPa}) \\
\end{array}$ & & \\
\hline \multirow[t]{2}{*}{1} & $\mathrm{~J} \times \mathrm{E}$ Hybrid, Maine & & 1 & 38 & $\begin{array}{l}6827 \\
(0.36)\end{array}$ & $\begin{array}{l}31.04 \\
(0.31)\end{array}$ & $\begin{array}{c}5772 \\
(0.28)\end{array}$ & $\begin{array}{l}55.48 \\
(0.18)\end{array}$ & $\begin{array}{c}0.404 \\
(0.116)\end{array}$ & $\begin{array}{l}12.98 \\
(0.06)\end{array}$ \\
\hline & & & 2 & 36 & $\begin{array}{l}7575 \\
(0.19\end{array}$ & $\begin{array}{l}30.93 \\
(0.27)\end{array}$ & $\begin{array}{c}6607 \\
(0.19)\end{array}$ & $\begin{array}{l}54.74 \\
(0.18)\end{array}$ & $\begin{array}{c}0.403 \\
(0.089)\end{array}$ & $\begin{array}{l}13.01 \\
(0.07)\end{array}$ \\
\hline \multirow[t]{3}{*}{2} & European, Maine & & 1 & 100 & $\begin{array}{l}11071 \\
(0.27)\end{array}$ & $\begin{array}{l}47.28 \\
(0.36)\end{array}$ & $\begin{array}{c}8783 \\
(0.22)\end{array}$ & $\begin{array}{l}59.30 \\
(0.16)\end{array}$ & $\begin{array}{c}0.470 \\
(0.101)\end{array}$ & $\begin{array}{l}14.19 \\
(0.07)\end{array}$ \\
\hline & & & 2 & 86 & $\begin{array}{l}11417 \\
(0.28)\end{array}$ & $\begin{array}{l}45.12 \\
(0.32)\end{array}$ & $\begin{array}{c}9434 \\
(0.20)\end{array}$ & $\begin{array}{l}71.86 \\
(0.11)\end{array}$ & $\begin{array}{c}0.464 \\
(0.103)\end{array}$ & $\begin{array}{l}13.84 \\
(0.04)\end{array}$ \\
\hline & & & 3 & 91 & $\begin{array}{l}10336 \\
(0.28)\end{array}$ & $\begin{array}{l}38.61 \\
(0.37)\end{array}$ & $\begin{array}{c}8964 \\
(0.16)\end{array}$ & $\begin{array}{l}67.85 \\
(0.13)\end{array}$ & $\begin{array}{c}0.461 \\
(0.084)\end{array}$ & $\begin{array}{l}13.70 \\
(0.05)\end{array}$ \\
\hline \multirow[t]{2}{*}{3} & Japanese, New Brunswick & & 1 & 73 & $\begin{array}{l}8256 \\
(0.31)\end{array}$ & $\begin{array}{l}40.05 \\
(0.31)\end{array}$ & $\begin{array}{l}7083 \\
(0.27)\end{array}$ & $\begin{array}{l}65.37 \\
(0.20)\end{array}$ & $\begin{array}{c}0.448 \\
(0.094)\end{array}$ & $\begin{array}{l}12.80 \\
(0.05)\end{array}$ \\
\hline & & $r$ & 2 & 53 & $\begin{array}{c}8693 \\
(0.25)\end{array}$ & $\begin{array}{l}38.77 \\
(0.29)\end{array}$ & $\begin{array}{l}7030 \\
(0.20)\end{array}$ & $\begin{array}{l}60.42 \\
(0.20)\end{array}$ & $\begin{array}{c}0.434 \\
(0.081)\end{array}$ & $\begin{array}{l}12.80 \\
(0.04)\end{array}$ \\
\hline \multirow[t]{2}{*}{4} & European, Nova Scotia & & 1 & 133 & $\begin{array}{c}5974 \\
(0.21)\end{array}$ & $\begin{array}{l}28.73 \\
(0.30)\end{array}$ & $\begin{array}{c}5102 \\
(0.28)\end{array}$ & $\begin{array}{l}51.70 \\
(0.16)\end{array}$ & $\begin{array}{c}0.407 \\
(0.061)\end{array}$ & $\begin{array}{l}12.42 \\
(0.04)\end{array}$ \\
\hline & & & 2 & 14 & $\begin{array}{l}5841 \\
(0.22)\end{array}$ & $\begin{array}{l}23.79 \\
(0.21)\end{array}$ & $\begin{array}{l}5386 \\
(0.21)\end{array}$ & $\begin{array}{l}48.48 \\
(0.19)\end{array}$ & $\begin{array}{c}0.388 \\
(0.077)\end{array}$ & $\begin{array}{l}12.45 \\
(0.04)\end{array}$ \\
\hline \multirow[t]{2}{*}{5} & European, PEI & & 1 & 45 & $\begin{array}{c}8878 \\
(0.25)\end{array}$ & $\begin{array}{l}43.84 \\
(0.33)\end{array}$ & $\begin{array}{c}7131 \\
(0.27)\end{array}$ & $\begin{array}{l}6374 \\
(0.17)\end{array}$ & $\begin{array}{c}0.466 \\
(0.069)\end{array}$ & $\begin{array}{l}13.28 \\
(0.04)\end{array}$ \\
\hline & & & 2 & 31 & $\begin{array}{l}9123 \\
(020)\end{array}$ & $\begin{array}{l}35.73 \\
(0.27)\end{array}$ & $\begin{array}{l}7866 \\
(0.19)\end{array}$ & $\begin{array}{l}65.05 \\
(0.13)\end{array}$ & $\begin{array}{c}0.441 \\
(0.082)\end{array}$ & $\begin{array}{l}13.33 \\
(0.09)\end{array}$ \\
\hline
\end{tabular}

${ }^{1}$ Values shown for properties are means with coefficient of variation given in parentheses

${ }^{2} \log$ position : 1 = base $\log , 2$ = second $\log$ from base, 3 = third $\log$ from base 


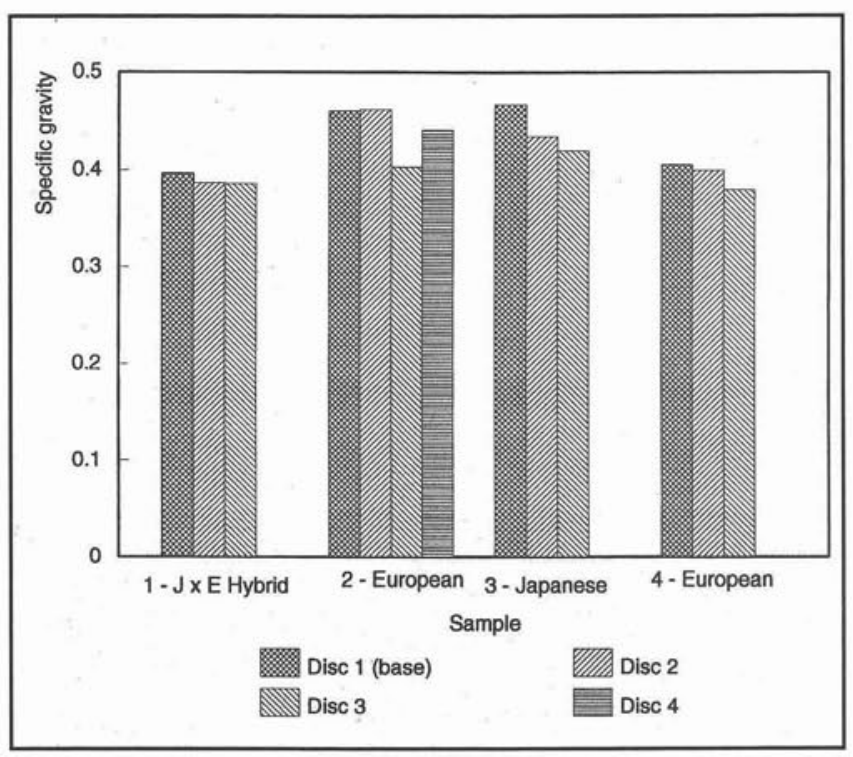

Figure 2. Axial variation of specific gravity.

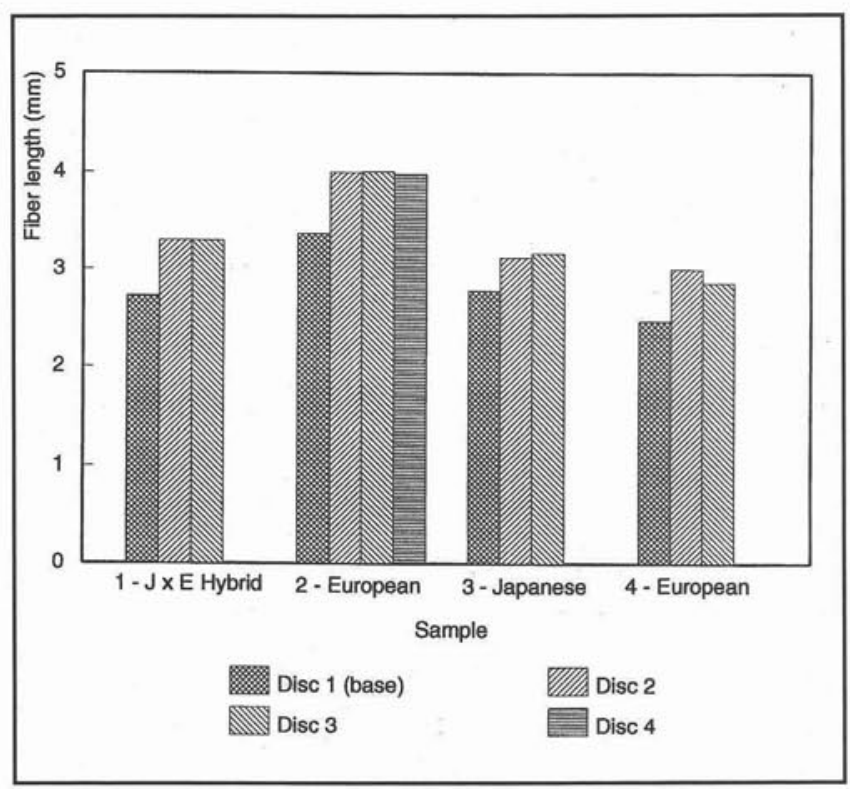

Figure 3. Axial variation of fiber length.

\section{Results and Discussion}

\section{Yields for Structural Grade Lumber}

Structural grading was performed according to Canadian visual grading rules (NLGA 1987) by a grading inspector from the Maritime Lumber Bureau, Amherst, Nova Scotia. The grades sorted were : Select Structural (SS), No.1, No.2, No.3 and Economy (E). The grade yield results are summarized (Table 2).

Knots are a primary growth feature governing visual grade yields. The presence of knots, their size and distribution, in most cases, determines the grade of a piece of lumber. The size and frequency of knots were relatively large compared with lumber of other native softwood species. This explains the relatively low yields for the SS grade. The grade yields for Japanese larch were, however, better than those obtained by Fowler et al. (1988)

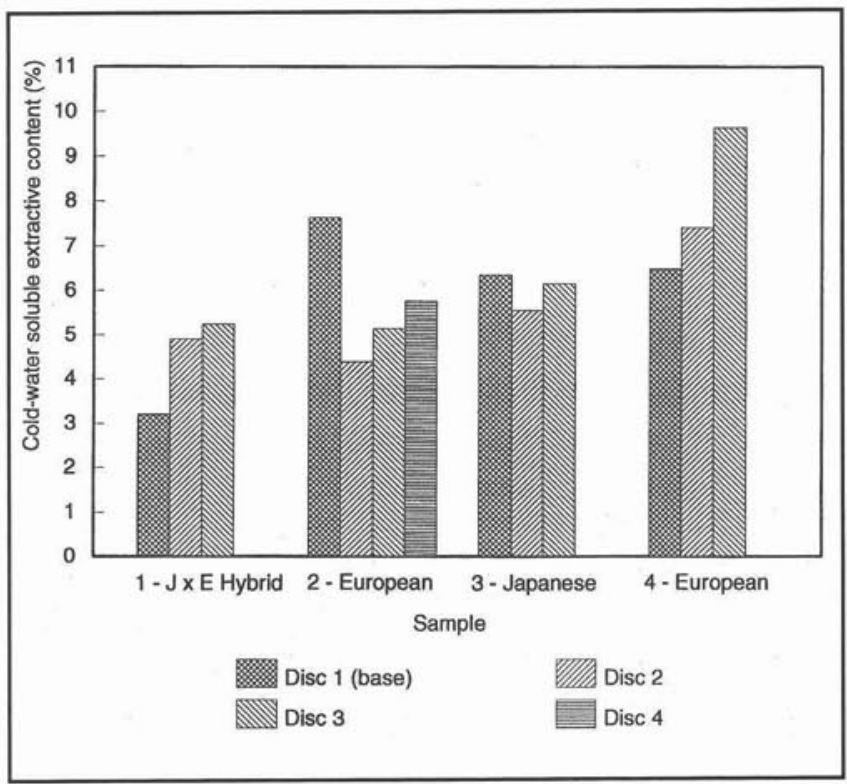

Figure 4. Axial variation of cold-water soluble extractive content.

for the same species. They obtained $45 \%$ and $38 \%$ yields for No.1 and No.2 grades respectively.

\section{Lumber Properties}

The summary statistics for all tested properties are shown (Table 3). When considering mechanical properties it is perhaps not surprising to find that the mature European larch of sample two produced wood with the best quality. Taking into consideration the age and growth rate, it seemed appropriate to compare mechanical properties of samples 1,3 and 5. The Japanese larch has similar mechanical properties to those of European larch despite a 20\% faster growth rate. The European $\times$ Japanese hybrid from Maine, USA has somewhat lower mechanical properties, perhaps due to its faster growth rate which led to a lower wood specific gravity.

The small clear bending tests were included to enable a comparison with corresponding properties for other native and exotic softwood species. Such a comparison (Table 4) indicated that MOE and MOR of the mature European larch sample was comparable with those of native balsam fir, white spruce, black spruce and red spruce. Not surprisingly the two juvenile larch samples (1 and 4) had vastly inferior MOE and MOR values. The Japanese larch sample from New Brunswick and European larch sample from PEI had similar MOE and MOR values. Their properties were comparable with plantation grown Norway spruce of similar age from New Brunswick and Nova Scotia (Chui 1993). The larch samples, however, had much higher mean specific gravities than Norway spruce.

\section{Basic Properties of Wood Material}

Basic wood properties including fiber length, cold-water soluble extractive content, and specific gravity were determined for samples one, two, three and four. The juvenile European larch from Nova Scotia had a high cold-water soluble extractive content, low specific gravity and short fiber length, indicating that the wood is less suitable for use as pulping material compared with the other samples (Table 5). It must be stressed, however, that this is most probably an age effect rather than a 


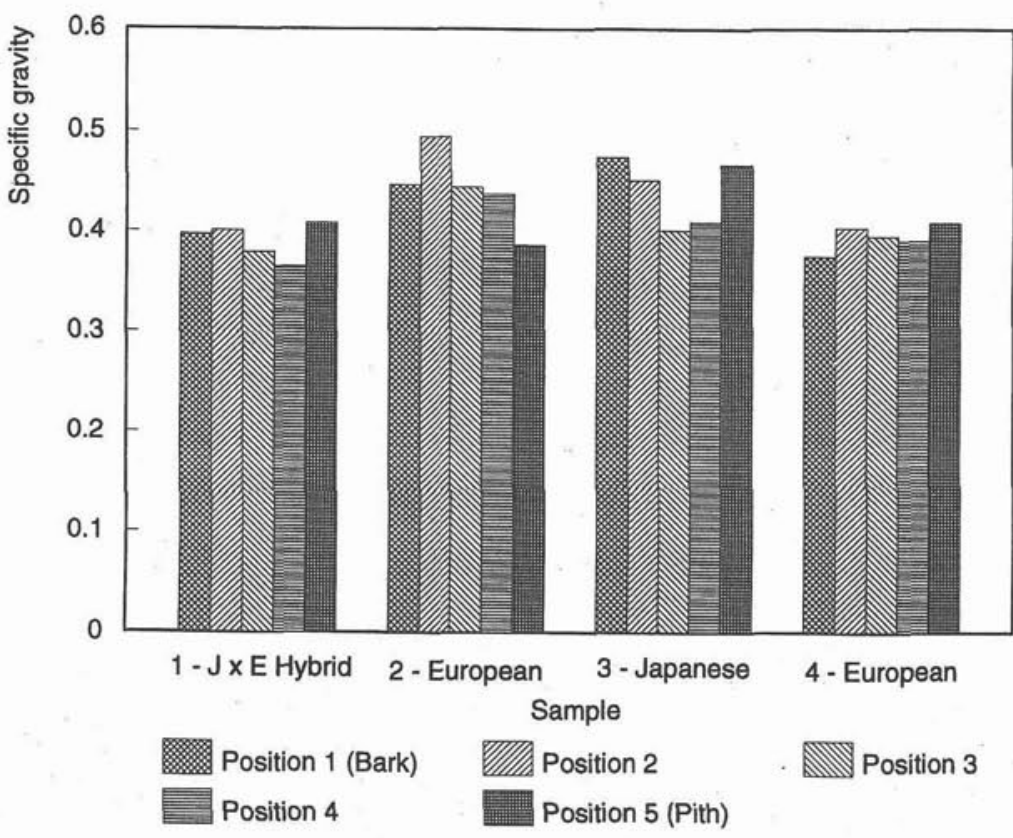

Figure 5. Radial variation of specific gravity.

species effect, as it seems certain that with increasing age fiber length and specific gravity will improve (see sample two). The finding with respect to extractive content is contrary to the previous belief that juvenile wood has lower extractive content because of the small proportion of heartwood in a juvenile stem (Isebrands and Hunt 1975). The extractive content of juvenile wood deserves further study. The other three more mature samples had significantly better wood properties from the standpoint of pulp production.

When comparing these properties with other species (Table 6) it should be noted that the sampling methods differed. For instance, Einspahr et al. (1983) measured fiber length at the fifteenth growth ring of three trees, while Kaya (1990) gave the weighted average fiber length for a complete stem based on the readings measured at regularly spaced locations both along the stem and from the pith to bark of one tree. Nonetheless, the quoted values are probably close to the "true" average of the sample tested in each case. Examination of the results shows that, with the possible exception of the juvenile European larch from Nova Scotia, the three measured properties of the tested larch samples were similar to those of some native and exotic softwood species planted in North America. This indicates that substituting traditional softwood species with exotic larch for pulp and paper appears feasible.

\section{Axial Variation of Wood Properties}

Mean lumber properties when the results are segregated based on position of test pieces along tree stem (Table 7) showed that the mechanical properties of lumber do not appear to differ along the tree stem. The lack of a clear trend for these exotic larch

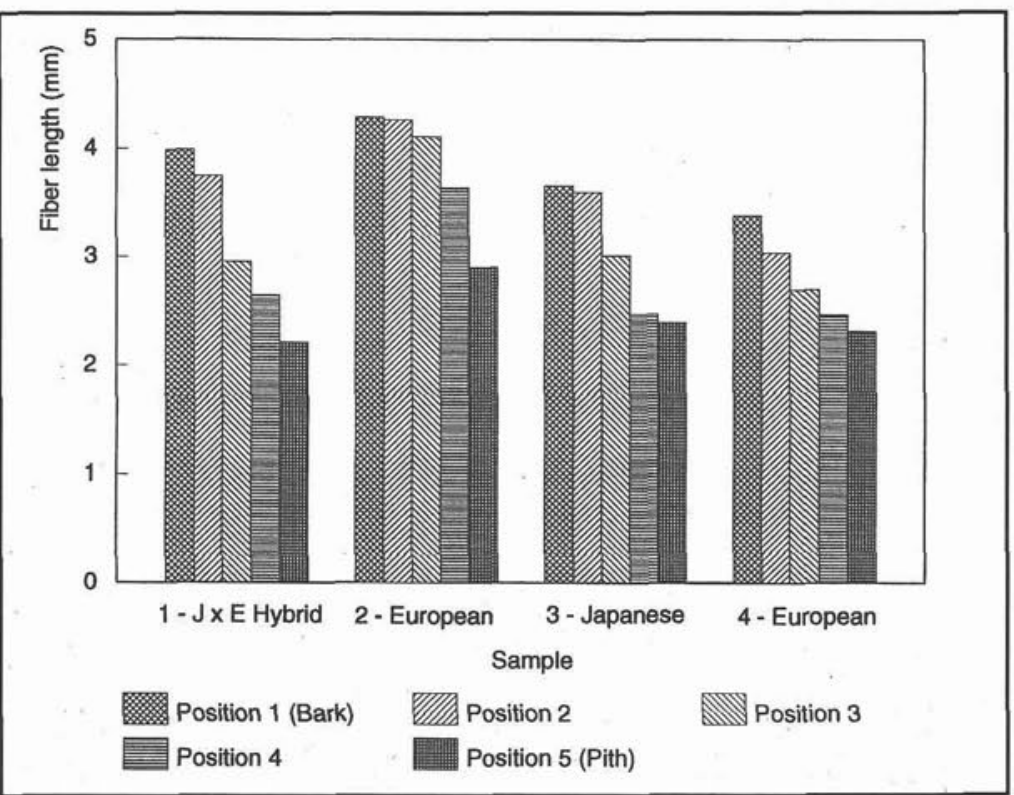

Figure 6. Radial variation of fiber length. 
Figure 7. Radial variation of cold-water soluble extractive content.

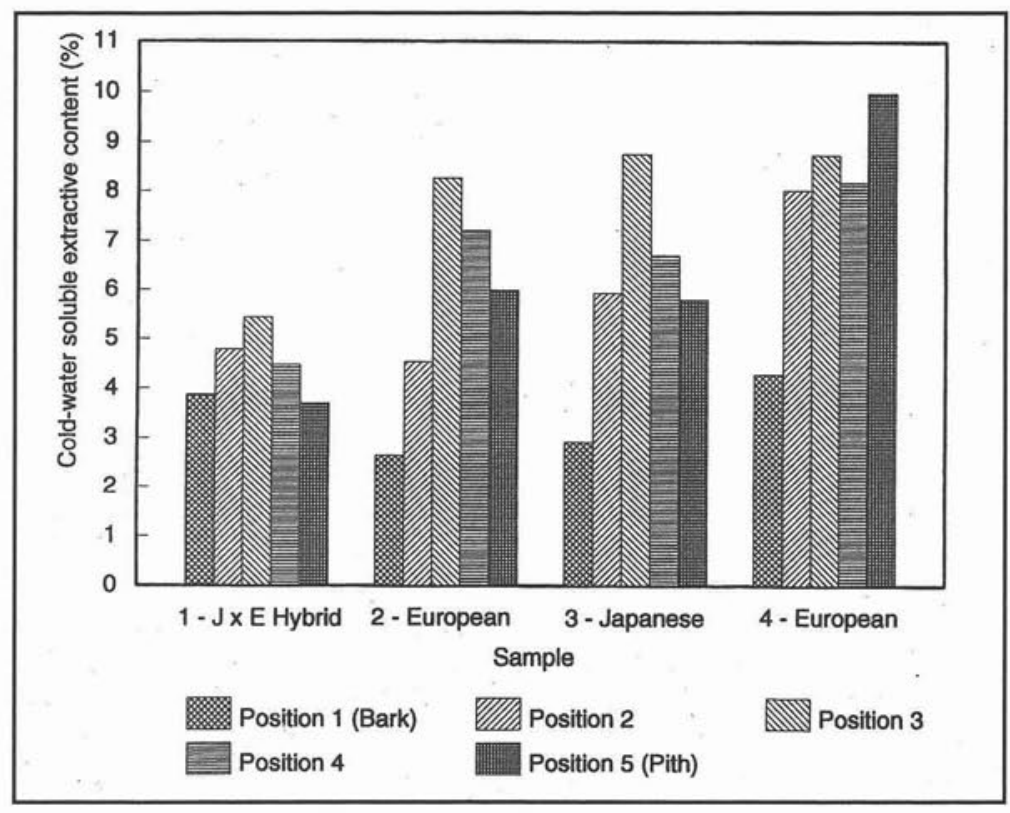

species is different from that observed for plantation grown Norway spruce (Chui 1993), which showed a very pronounced decreasing trend for mechanical properties with increasing height in the tree stem.

For specific gravity, a trend of decreasing specific gravity with increasing height in a tree stem was noted, with the exception of European larch from Maine (sample two) which showed an increase in specific gravity from disc three to four (Fig. 2). The cause of this slight deviation is not known.

Fibers at stump level (disc one) were shorter than those at higher levels (Fig. 3). No clear differences in fiber length were detected among the other heights. It is not known why this trend occured, but it was similar to results obtained by Keith and Chauret (1988) for European larch. For the cold-water soluble extractive content, the trends were also unclear (Fig. 4). A study by Isebrands and Hunt (1975) on 10-year-old Japanese larch showed that the central part of the base of a tree contained a higher extractive content than other parts of the tree. This agrees with results obtained here for samples two (European larch) and three (Japanese larch), but not with the other two. Thus, further investigations are required if a better understanding of variation in extractive content is desired.

\section{Radial Variation of Basic Wood Properties from the Pith to Bark}

The variation of specific gravity from the pith to bark is illustrated (Fig. 5). Each value is an average obtained for all heights. Positions one and five correspond to the locations closest to the bark and pith respectively. There was an initial reduction in specific gravity going from the pith to bark, and then an increase towards the heartwood/sapwood boundary. Afterwards, with the exception of the Japanese larch, a slight drop in specific gravity was observed moving from the heartwood/sapwood boundary towards the bark. This trend belongs to the Type two density variation as defined by Panshin and De Zeeuw (1980), and appears similar to that for European larch tested by Keith and Chauret (1988).

Fiber length clearly increased from the pith to bark (Fig. 6). This was largely due to the shorter fiber length found in the juve- nile wood (Larson 1969; Kaya 1990). The ratio of mature to juvenile fiber lengths could be as high as two (sample one). This highlights the problems encountered with the presence of juvenile wood in pulping material. The extractive content results (Fig. 7) showed an interesting trend in which the highest content is found in the heartwood close to the heartwood/sapwood boundary. Again, similar findings were obtained by Keith and Chauret (1988). This phenomenon is probably a result of the large amount of chemicals formed at the early stage of heartwood formation. As expected, extremely low extractive content was found in the sapwood portion.

\section{Conclusions}

1. Yields for structural grade lumber of exotic larch species are low because of the size and distribution of knots in processed lumber.

2. Mechanical properties of wood from mature European larch are comparable with corresponding published data for some commercially important native softwood species (e.g. black spruce, white spruce, red spruce and balsam fir). In contrast with most softwood species, no significant axial variation in mechanical properties was observed in this species. The younger larch samples exhibited lower mechanical properties, in comparison with the published data.

3. Fiber length, specific gravity and extractive content of the exotic larch species were similar to published data for some commercially important softwood species, indicating the potential for substituting these exotic larch species with traditional pulping species.

4. Contrary to the common belief, the youngest European larch (age 17) sample had the highest mean extractive content.

5 From the pith to bark the highest extractive content was detected in the newly formed heartwood.

\section{Acknowledgements}

This project was conducted at the Wood Science and Technology Centre, Faculty of Forestry and Environmental Management, University of New Brunswick. Funding was provided by the COOPERATION Agreement Programs on Forest 
Development in New Brunswick and Nova Scotia. Contributions in the form of test material, transportation of sawlogs and staff time were received from the following organizations: Department of Natural Resources, Nova Scotia; Canadian Forest Service, Natural Resources Canada; Department of Agriculture, Fisheries and Forestry, Prince Edward Island; S.D. Warren Company, Maine; Scott Worldwide, Nova Scotia; Georgia-Pacific Corp, USA; University of Minnesota Aspen/Larch Genetics Cooperation, USA; Maritime Lumber Bureau. Their contributions are gratefully acknowledged.

\section{References}

ATSM. 1992. Standard method of testing small clear specimens of timber. ASTM D143-83, American Society of Testing and Materials, Philadelphia, PA.

Chui, Y. H. 1993. Evaluation of some structural properties of lumber from Norway spruce trees grown in the Maritimes. Report No. FC9208, Wood Science and Technology Centre, University of New Brunswick, Fredericton, NB.

Einspahr, D.W., T. J. McDonough and T. Joachimides. 1983. Kraft pulping characteristics of European, Japanese, and European $\mathrm{x}$ Japanese larch hybrids. TAPPI Journal 66(8): 72-76

FPL. 1987. Wood Handbook: Wood as an engineering material. Agriculture Handbook No.72. USDA Forest Products Laboratory, Madison, WI.

Fowler, D.P. 1986. Strategy for the genetic improvement of Larix species and hybrids in the Maritimes. Proceedings of 1986 Larch Workshop, New Brunswick Forest Research Advisory Committee, Fredericton, NB.

Fowler, D.P., J. D. Simpson, Y.S. Park and M. H. Schneider. 1988. Yield and wood properties of 25-year-old Japanese Larch of different provenances in eastern Canada. Forestry Chronicle 64(4): 475-479 Hatton, J. V. 1986. Chemical and pulping properties. Proceedings of 1986 Larch Workshop, New Brunswick Forest Research Committee, Fredericton, NB.

Hillis, W.E. 1962. Wood extractives. Academic Press Inc., New York, NY.

Isebrands, J.G. and C. M. Hunt. 1975. Growth and wood proper- ties of rapid-grown Japanese larch. Wood and Fiber 7(2): 119-128 Isebrands, J.G., D. W. Einspahr, J. E. Phelps and J. B. Crist. 1982. Kraft pulp and paper properties of juvenile hybrid larch grown under intensive culture. TAPPI Journal 65(9): 122-126

ISO. 1985. Solid timber in structural sizes. Determination of some physical and mechanical properties. ISO 8375. International Organization for Standardization, Geneva, Switzerland.

Kaya, F. 1990. Variation in some properties and effect of moisture on clear wood from red pine. MScFE thesis, University of New Brunswick, Fredericton, NB.

Keith, C. T. and G. Chauret. 1988. Basic wood properties of European larch from fast-grown plantations in eastern Canada. Can. J. For. Res. 18: 1325-1331.

Ker, M.F., S. A. Borland and J. F. Coles. 1983. Site-index curves for black spruce, white spruce, jack pine and tamarack in New Brunswick, New Brunswick Executive Forest Research Committee Inc., Fredericton, NB.

Larson, P. R. 1969. Wood formation and the concept of wood quality. Bulletin 74, Yale University, New Haven, CT.

Loo-Dinkins, J.A., D. P. Fowler, Y.S. Park and E. K. Morgenstern. 1992. Performance of Larix leptolepis, L. Decidua and their hybrids in the Maritimes regions of Canada. Paper presented at IUFRO Working Party S2.02-07 Meeting, Berlin, Germany.

MacGillivaray, H.G. 1969. Larches for reforestation and tree improvement in eastern Canada. Forestry Chronicle 45: 440-444

Mullins, E. F. and T. S. McKnight. 1981. Canadian woods, their properties and uses. University of Toronto Press, Toronto, ON.

NLGA. 1987. Standard grading rules for Canadian lumber. National Lumber Grades Authority, Vancouver, BC.

Olson, A. R., N. V. Poletika and H. W. Hicock. 1947. Strength properties of plantation-grown coniferous woods. Bulletin 511, Connecticut Agriculture Experiment Station, New Haven, CT.

Panshin, A.J. and C. De Zeeuw. 1980. The textbook of wood technology. 4th edition, McGraw-Hill, New York, NY.

Park, Y.S. and D. P. Fowler. 1983. A provenance test of Japanese larch in eastern Canada, including comparative data on European larch and tamarack, Silave Genet. 32: 96-101

TAPPI. 1988. Water solubility of wood and pulp. Standard T207 om88. TAPPI. 